\title{
ANALISIS MANFAAT PENGGUNAAN APLIKASI ZOOM DALAM PEMBELAJARAN DARING BAGI GURU DAN SISWA DI SEKOLAH DASAR
}

\author{
Eko Kuntarto ${ }^{1}$, Muhammad Sofwan ${ }^{2}$, Nurlaili Mulyani ${ }^{3}$. \\ ekokuntarto28@unja.ac.id ${ }^{1}$, muhammad.sofwan@unja.ac.id², \\ nurlailimulyani@gmail.com ${ }^{3}$ \\ PGSD, FKIP, Universitas Jammbi ${ }^{1,2,3}$
}

\begin{abstract}
Abstrak: Penelitian ini bertujuan untuk mendeskripsikan manfaat dari penggunaan aplikasi zoom dalam pembelajaran daring bagi guru dan siswa di Sekolah Dasar.Jenis penelitian dalam penelitian ini yaitu penelitian kualitatif dengan jenis fenomenologi. Sampel dalam penelitian ini sebanyak 8 informan, terdiri dari dua guru kelas $\mathrm{V}$ dan enam siswa kelas Vc. Hasil dari penelitian ini adalah penggunaan aplikasi zoom memberikan banyak manfaat bagi guru dan siswa selama pembelajaran daring di masa pandemi. Manfaat bagi guru diantaranya memudahkan mencapai tujuan pembelajaran, memudahkan berinteraksi bersama siswa, memberikan variasi dalam pembelajaran daring, menciptakan pembelajaran daring yang aktif, sedangkan manfaat penggunaan zoom bagi siswa diantaranya memudahkan memahami materi, meningkatkan semangat belajar daring, menghilangkan rasa bosan belajar daring. Manfaat yang dirasakan guru dan siswa tersebut memberikan dampak yang positif dalam pembelajaran daring sehingga menjadi lebih efektif.
\end{abstract}

Kata kunci: manfaat zoom, pembelajaran daring, guru dan siswa, sekolah dasar.

\section{ANAL YSIS OF THE BENEFITS OF USING THE ZOOM APP IN ONLINE LEARNING FOR TEACHERS AND STUDENTS IN ELEMENTARY SCHOOLS}

\begin{abstract}
This study aims to describe the benefits of using the zoom app in online learning for teachers and students in elementary schools. The type of research in this study is qualitative research with phenomenological type. The sample in this study was 8 informants, consisting of two grade $v$ teachers and six $v c$ grade students. Benefits for teachers include making it easier to achieve learning objectives, facilitating interaction with students, providing variations in online learning, creating active online learning,
\end{abstract}


Eko, Muhammad, Nurlaili. Analisis Manfaat Penggunaan Aplikasi...

while the benefits of using zoom for students include making it easier to understand materials, improving the spirit of online learning, eliminating the boredom of online learning. The benefits felt by teachers and students have a positive impact in online learning so that it becomes more effective.

Keywords: benefits of zoom, online learning, teachers and students, elementary school.

\section{PENDAHULUAN}

Dengan adanya covid-19 yang melanda Indonesia di awal Maret 2020, hingga saat ini masih memberikan dampak di setiap aspek kehidupan termasuk di bidang pendidikan. Covid-19 merupakan penyakit menular, yang berarti dapat menyebar, baik secara langsung maupun tidak langsung, dari satu orang ke orang lain (Mustakim, 2020). Penyakit ini menyerang sistem pernapasan pada manusia, yang mana penyebaran Covid-19 masih berlangsung dengan cepat. Salah satu cara memutuskan rantai penyebaran Covid-19 yaitu dengan melakukan pembatasan interaksi masyarakat. Kemendikbud untuk memutuskan rantai penyebaran covid-19 melalui Surat Edaran No 4 Tahun 2020 yang dikeluarkan Kementrian Pendidikan dan Kebudayaan Nasional tentang Pelaksanaan Kebijakan Pendidikan Dalam Masa Darurat Penyebaran Covid-19, dimana pembelajaran yang ada wajib dilaksanakan secara daring.

Meskipun pendidikan dilaksanakan secara daring tetapi pendidikan memegang peran penting dalam perbaikan kualitas generasi sebuah negara, tujuan dari pendidikan harus tetap diwujudkan. Pendidikan memiliki tujuan untuk mengembangkan potensi siswa supaya melahirkan manusia yang bertakwa kepada Tuhan Yang Maha Esa, menjadikan manusia dan warga negara yang seutuhnya (UU No 20 Tahun 2003). Salah satu dampak dari wabah pandemi Covid-19 pada bidang pendidikan yaitu pembelajaran yang awalnya dilaksanakan secara luring kini telah dialihkan secara daring.

Pembelajaran daring merupakan sistem pembelajaran yang dilakukan dengan menggunakan platform yang dapat menunjang proses pembelajaran meskipun jarak jauh (Handarini \& Wulandari, 2020). Pembelajaran daring adalah kegiatan belajar yang dilaksanakan dalam jarak jauh melalui media berupa internet dan alat seperti komputer dan smartphone (Putria dkk, 2020). Pembelajaran daring lebih menekankan pada ketelitian dan kejelian peserta didik dalam menerima dan mengolah informasi yang disajikan secara online (Riyana, 2019). Maka dapat disimpulkan bahwa pembelajaran daring adalah pembelajaran yang dilaksanakan dalam kondisi berjauhan dengan 
Eko, Muhammad, Nurlaili. Analisis Manfaat Penggunaan Aplikasi...

memanfaatkan media elektronik dan jaringan internet, sehingga memudahkan siswa untuk belajar.

Pembelajaran masa pandemi yang menggunakan pembelajaran daring dipilih untuk merencanakan proses pembelajaran yang sesuai dengan kondisi saat ini dimana pembelajaran tatap muka tidak dapat dilaksanakan. Pelaksanaan pembelajaran daring mampu untuk menunjang dan memudahkan proses pembelajaran di sekolah (Sadikin \& Hamidah, 2020). Proses pembelajaran daring bertujuan agar kegiatan belajar mengajar menjadi lebih mudah dan lancar serta dapat meningkatkan minat dan hasil proses belajar mengajar. Pembelajaran daring bertujuan memberikan fasilitas pembelajaran yang bermutu dalam jaringan (daring) yang bersifat utuh dan terbuka untuk menjangkau peminat yang lebih banyak dan luas (Sofyana \& Roza, 2019)

Untuk menunjang pembelajaran daring yang dilakukan demi mencapai tujuan pembelajaran, guru harus memanfaatkan perkembangan Teknologi Informasi dan Komunikasi (TIK). Dimanfaatkannya teknologi sebagai media pembelajaran dalam proses belajar mengajar, dapat mempermudah cara mengajar dalam berkomunikasi dan berinteraksi dengan para siswa baik di dalam kelas maupun di luar kelas (Anshori, 2018). Penggunaan TIK tidak hanya dapat mendukung perkembangan kognitif siswa tetapi juga meningkatkan motivasi belajar dan interaksi siswa dalam pembelajaran (Suryani, 2010). Untuk memenuhi standart pendidikan dengan pemanfaatan Teknologi Informasi dengan menggunakan perangkat komputer atau gadget yang saling terhubung antara siswa dan guru sehingga melalui pemanfaatan teknologi tersebut proses belajar mengajar bisa tetap dilaksanakan dengan baik (Pakpahan \& Fitriani, 2020).

Perkembangan TIK sebagai media pembelajaran harus benar-benar dipertimbangakan karena jka tidak tepat guna dapat memberikan dampak buruk pada manfaat belajaran. Salah satu hasil dari perkembangan TIK yang dapat digunakan guru sebagai media guna menunjang pembelajaran daring di masa pandemi yaitu aplikasi zoom. Zoom dapat dikategorikan sebagai media pembelajaran online yang dapat diartikan sebagai suatu jenis belajar mengajar yang memungkinkan tersampaikannya bahan ajar ke siswa dengan menggunakan media Internet (Monica \& Fitriawati, 2020). Aplikasi zoom merupakan sebuah sebuah media pengajaran daring yang berupa aplikasi yang mempunyai fitur konferensi jarak jauh dengan menyatukan konferensi video, obrolan online, pertemuan online dan juga bisa dikolaborasikan dengan seluler (Rosyid 
Eko, Muhammad, Nurlaili. Analisis Manfaat Penggunaan Aplikasi...

dkk., 2020). Selain itu penggunaan zoom dapat memberikan dampak yang positif bagi sistem pembelajaran daring di sekolah-sekolah. Melalui zoom dijadikan pembelajaran online jarak jauh menjadikan pembelajaran lebih efektif, karena zoom menyediakan video konferensi yang dapat dijangkau oleh seluruh partisipan atau siswa dan guru (Brahma, 2020).

Berdasarkan hasil studi pendahuluan yang dilasanakan di Sekolah Islam Terpadu Ahmad Dahlan Kota Jambi kelas VC didapati bahwa proses pembelajaran yang dilaksanakan di sekolah ini dilakukan secara daring sejak adanya pandemi Covid-19. Terdapat beberapa media pembelajaran yang digunakan dalam menunjang kegiatan pembelajaran daring diantaranya aplikasi zoom, google classroom, google form, WhatsApp Group dan video pembelajaran. Menurut wali kelas dalam menunjang pembelajaran daring untuk siswa, maka beliau menggunakan salah satu perkembangan TIK yaitu aplikasi Zoom. Selain itu pembelajaran daring dikombinasikan juga dengan grup whatsapp dan video pembelajaran yang dibuat sendiri. Guru mengemukakan bahwa aplikasi zoom yang digunakan dalam pembelajaran daring saat ini sangat banyak memberikan manfaat baik bagi guru maupun siswa.

Berdasarkan latar belakang yang telah diapaparkan tujuan dalam penelitian ini yaitu untuk menganalisis manfaat dari penggunaan aplikasi zoom dalam pembelajaran daring bagi guru dan siswa di sekolah dasar. Hal ini dikarenakan dalam pembelajaran daring ataupun pembelajaran jarak jauh yang dilaksanakan khususya pada jenjang sekolah dasar, guru dituntut untuk mampu memilih media yang efektif sebagai penunjang pembelajaran yang dilaksanakan.

\section{METODE}

Penelitian ini menggunakan pendekatan kualitatif. Metode penelitian kualitatif digunakan untuk menjawab masalah penelitian terkait data berupa narasi yang berasal dari wawancara, observasi, dan ekstraksi dokumen (Wahidmurni, 2017). Dengan jenis penelitian fenomenologi. Studi fenomenologi bertujuan untuk menggali informasi secara mendalam para subjek mengenai pengalamannya dalam satu peristiwa (Habiansyah, 2008). Penelitian ini dilaksanakan di kelas VC Sekolah Dasar Islam Terpadu Ahmad Dahlan, pada semester genap tahun ajaran 2020/2021. Dengan tahap persiapan, tahap pelaksanaan, dan tahap penyelesaian. 
Eko, Muhammad, Nurlaili. Analisis Manfaat Penggunaan Aplikasi...

Data dalam penelitian ini dibedakan menjadi dua yaitu data primer dan data sekunder. Sumber data primer dalam penelitian ini terdiri dari 2 orang guru kelas V dan 6 orang siswa kelas VC. Sedangkan sumber data sekunder dalam penelitian ini yaitu diperoleh dari buku-buku dan jurnal yang relevan dengan penelitian ini. Teknik pengumpulan data yang digunakan dalam penelitian ini yaitu observasi dan wawancara mendalam.

Untuk menyajikan data agar mudah dipahami, maka peneliti menggunakan teknik analisis model Miles dan Huberman dengan tahapan 1) Pengumpulan data, pada analisis model pertama dilakukan pengumpulan data dari berbagai kegiatan antara lain wawancara, observasi, dan berbagai dokumentasi berdasarkan topik masalah penelitian yang kemudian dikembangkan penajaman data melalui pencarian data selanjutnya; 2) Reduksi data, reduksi data adalah kegiatan mengolah data yang diperoleh dan dianalisis dengan sedemikian rupa sehingga dapat menarik simpulan dan diverifikasi (Miles dan Huberman, 2007); 3) Penyajian data, penyajian data dilakukan guna menemukan polapola yang bermakna. memberikan adanya penarikan simpulan dan memberikan tindakan (Miles dan Huberman, 2007); 4) Penarikan Kesimpulan, tahap penarikan kesimpulan adalah bagian dari suatu kegiatan konfigurasi yang utuh (Miles dan Huberman, 2007).

\section{HASIL}

Berdasarkan hasil observasi dan wawancara bersama guru dan siswa, didapati beberapa manfaat penggunaan aplikasi zoom dalam pembelajaran daring bagi guru dan siswa.

\section{Manfaat Penggunaan Zoom Bagi Guru}

a. Memudahkan Mencapai Tujuan Pembelajaran

Berdasarkan hasil wawancara dan observasi, diketahui bahwa dalam pembelajaran daring guru menyampaikan tujuan diawal pembelajaran. Penyampaian ini bertujuan untuk memberitahukan ke siswa mengenai apa saja yang harus mereka capai saat pembelajaran. Guru mengungkapkan dengan menggunakan aplikasi zoom mampu untuk mencapai tujuan pembelajaran yang telah dirancang hingga $80 \%$.

Demi mencapai tujuan tersebut guru kelas membuat suasana pembelajaran di zoom sama seperti pembelajaran tatap muka di kelas. Guru 


\section{Eko, Muhammad, Nurlaili. Analisis Manfaat Penggunaan Aplikasi...}

memulai pembelajaran dengan memberikan semangat kepada siswa, mengkondisikan siswa agar siap untuk mengikuti pembelajaran. Setelah itu guru menyampaikan tujuan, menjelaskan materi pembelajaran, memberikan kesempatan siswa untuk bertanya, memberikan penugasan pada siswa, dan mengevaluasi hasil yang didapat oleh siswa.

b. Memudahkan Berinteraksi Bersama Siswa

Berdasarkan hasil wawancara dan observasi didapati bahwa aplikasi zoom ini mampu menampung seluruh siswa dengan satu kali pertemuan. Guru mengungkapkan bahwa dalam suasana pembelajaran daring ini aplikasi zoom membantu guru untuk mempermudah berkomunikasi dengan siswa dibanding aplikasi whatsapp. Disamping itu banyak fitur yang menunjang pembelajaran daring lebih mudah tersampaikan dengan baik kepada siswa di rumah. Guru dapat menampilkan materi sekaligus menjelaskannya langsung kepada siswa melalui aplikasi zoom.

Siswa dapat bertanya langsung kepada guru layaknya di dalam kelas. Pembelajaran tidak monoton hanya mengerjakan tugas saja, tetapi guru juga memberikan kuis kepada siswa. kuis tersebut berupa pertanyaan mengenai materi pembelajaran yang telah dilaksanakan. Siswa berlomba-lomba menjawab pertanyaan tersebut agar bisa mendapatkan point berupa bintang. Kemudian bintang tersebut dikumpulkan agar dapat menjadi bintang kelas. Bintang kelas bukan dia yang mendapatkan rangking 1 tetapi dia yang sering menjawab ketika pembelajaran berlangsung. Interaksi yang tercipta antara guru dengan siswa dalam pembelajaran melalui zoom mampu membuat pembelajaran terlaksana dengan baik.

c. Memberikan Variasi Dalam Pembelajaran Daring

Berdasarkan hasil wawancara dan observasi, diketahui bahwa penggunaan aplikasi zoom ini menjadi salah satu variasi yang digunakan guru untuk menunjang proses pembelajaran daring. Pada awalnya guru hanya menggunakan aplikasi whatsapp untuk menunjang proses pembelajaran daring. Kemudian guru mencoba untuk menggunakan aplikasi yang lain dan aplikasi tersebut adalah aplikasi zoom. Guru mengungkapkan bahwa sebagai seorang guru harus mampu menguasai perkembangan teknologi informasi dan 
Eko, Muhammad, Nurlaili. Analisis Manfaat Penggunaan Aplikasi...

komunikasi agar dapat menciptakan suasana baru bagi siswa supaya tidak bosan dalam belajar terutama belajar daring. Guru juga mengungkapkan bahwa setelah menggunakan aplikasi zoom untuk menunjang pembelajaran daring ternyata banyak kelebihan yang diperolehnya.

d. Menciptakan Pembelajaran Daring Yang Aktif

Berdasarkan hasil wawancara dan observasi didapati bahwa proses pembelajaran menggunakan aplikasi zoom ini cukup aktif. Dimana proses pembelajaran tidak monoton mengerjakan tugas saja, tetapi ada interaksi secara langsung antara guru dengan siswa dan siswa dengan siswa. sebelum pembelajaran dimulai guru memberikan kesempatan kepada siswa untuk saling menyapa satu sama lain sambil menunggu tema-teman yang lain bergabung ke dalam zoom. Siswa selalu diberi kesempatan oleh guru untuk bertanya apabila ada materi yang belum atau kurang dipahami. Kemudian di akhir pembelajaran guru memberikan kuis berupa pertanyaan seputar materi yang telah dipelajari. Siswa yang dapat menjawab pertanyaan diberikan reward berupa poin.

\section{Manfaat Penggunaan Zoom Bagi Siswa}

a. Memudahkan Memahami Materi

Berdasarkan hasil wawancara dan observasi didapati bahwa guru menyampaikan tujuan pembelajaran melalui fitur yang terdapat pada zoom yaitu share screen. Kemudian guru menjelaskan materi dengan menampilkan materi pembelajaran. penjelasan oleh guru dengan tampilan materi pembelajaran secara bersamaan membuat siswa lebih mudah memahami materi. Siswa juga mengungkapkan bahwa belajar dengan menggunakan zoom ini lebih mudah untuk memahami materi dibandingkan dengan aplikasi whatsapp.

Materi yang belum dipahami siswa dapat ditanyakan secara langsung kepada uru dan guru dapat menjawab pertanyaan tersebut secara langsung. ada yang menarik dari kegiatan pembelajaran melalui aplikasi zoom yaitu setelah proses pembelajaran berakhir uru menanyakan kepada siswa siapa saja yang belum paham terhadap pembelajaran yang telah dilaksanakan. Kemudian guru memberikan kesempatan kepada siswa yang belum paham untuk tetap berada 
Eko, Muhammad, Nurlaili. Analisis Manfaat Penggunaan Aplikasi...

di dalam zoom untuk mengikuti kembali pembelajaran dari awal yang akan diulang oleh guru dan yang sudah paham dapat meninggalkan zoom (leave).

b. Meningkatkan Semangat Belajar Daring

Berdasarkan hasil wawancara dan observasi, diketahui bahwa pada kegiatan pembelajaran siswa bersemangat karena dapat belajar bersama temanteman dan dapat melihat langsung guru menjelaskan pembelajaran. Pembelajaran daring yang tidak menggunakan zoom rentan membuat siswa tidak bersemangat dalam mengikuti pembelajaran karena mereka tidak dapat belajar bersama. Ketika menggunakan zoom mereka mengatakan bahwa lebih bersemangat belajarnya daripada belajar menggunakan media yang lain.

c. Menghilangkan Rasa Bosan Belajar Daring

Berdasarkan hasil wawancara dan observasi, didapati bahwa belajar melalui aplikasi zoom dapat menghilangkan rasa bosan siswa mengikuti pembelajaran daring. Siswa mengungkapkan bahwa karena mereka dapat bertemu serta belajar bersama guru dan teman-temannya serta materi yang diberikan guru juga menarik.

Siswa terlihat sangat antusias belajar melalui zoom karena kegiatan pembelajaran tidak monoton, tetapi siswa dapat mengikuti kegiatan pembelajaran layaknya di dalam kelas walaupun melalui aplikasi zoom. Beda halnya dengan belajar melalui whatsapp, siswa hanya diberikan tugas terus menerus, hal ini yang membuat siswa bosan.

Berdasarkan hasil penelitian yang telah didapatkan, aplikasi zoom memberikan banyak manfaat bagi guru dan siswa pada pembelajaran daring di masa pandemi ini. Manfaat tersebut akan membuat pembelajaran yang dilakukan oleh guru dapat mencapai tujuan yang telah dirancang sebelumnya. Adapun manfaat bagi guru diantaranya memudahkan mencapai tujuan, memudahkan berinteraksi bersama siswa, memberikan variasi dalam pembelajaran daring untuk siswa, dan menciptakan pembelajaran daring yang aktif.

\section{PEMBAHASAN}


Eko, Muhammad, Nurlaili. Analisis Manfaat Penggunaan Aplikasi...

Dalam pembelajaran daring saat ini pencapaian tujuan pembelajaran tetap harus diperhatikan oleh guru, hal ini guna untuk memenuhi kebutuhan siswa akan pemahaman terhadap materi yang diberikan. Menurut Kurniasari dkk., (2020) mengungkapkan bahwa baik pembelajaran daring maupun luring guru harus memperhatikan tercapainya tujuan pembelajaran. Guna mencapai tujuan pembelajaran daring diperlukan penggunaan media yang merupakan hasil dari perkembangan teknologi yang memungkinkan pembelajaran lebih efektif dan berorientasi tujuan (Kuntarto \& Asyhar, 2016). Salah satu media yang tepat untuk mencapai tujuan pembelajaran di masa pandemi saat ini adalah aplikasi zoom. Hal ini sejalan dengan Liu \& Ilyas, (2020) yang mengungkapkan bahwa pembelajaran daring yang menggunakan zoom memiliki pengaruh terhadap hasil belajar siswa, yang mana tercapainya minimal nilai 70 .

Selain itu demi mencapai tujuan pembelajaran tersebut diperlukan interaksi yang aktif antara guru dan siswa, terlebih di masa pandemi covid-19. Buana (2020) mengemukakan salah satu prinsip terjadinya pembelajaran daring yaitu tersedianya ruang bagi guru dan siswa untuk berinteraksi dua arah dan bersifat interaktif. Dengan meggunakan aplikasi zoom yang memiliki berbagai fitur didalamnya mampu untuk memfasilitasi interaksi yang aktif antara guru dan siswa. Pembelajaran daring menggunakan zoom yang memiliki fitur video conference dapat mengoptimalkan interaksi siswa dan siswa maupun siswa dan guru (Ismawati \& Prasetyo, 2020).

Pembelajaran daring saat ini rentan membuat siswa merasakan kebosanan saat belajar, seperti bosan ketika belajar dengan metode/media yang monoton. Oleh karena ini guru harus membuat sebuah variasi dalam pembelajaran daring agar siswa memiliki minat belajar yang baik. Salah satu upaya yang dapat dilakukan guru yaitu dengan cara menggunakan aplikasi zoom sebagai media pembelajaran, yang mana dapat memfasilitasi siswa untuk merasakan suasana beajar yang baru. Seperti dapat bertatap muka bersama teman dan guru, dan belajar bersama. Menurut Siahaan (2020) menyatakan bahwa pembelajaran yang bervariasi dapat memberikan manfaat untuk mengembangkan pemikiran siswa melalui analisis mereka sendiri.

Selain memberikan variasi dalam pembelajaran, penggunaan zoom juga mampu menciptakan pembelajaran daring yang lebih aktif, daripada media pembelaan yang lain. Dengan menggunakan zoom, guru bisa memberikan pembelajaran dan siswa bisa berkomunikasi langsung untuk menanyakan berbagai permasalahan dalam materi 
Eko, Muhammad, Nurlaili. Analisis Manfaat Penggunaan Aplikasi... pembelajaran secara interaktif dengan guru (Solihin, 2020). Dengan menggunakan zoom guru dapat membuat pembelajaran lebih menarik, karena aplikasi zoom ini memiliki fitur-fitur yang dapat menampilkan bahan ajar yang menarik kepada peserta didik. Pratama \& Mulyati (2020) mengungkapkan bahwa dalam pembelajaran daring siswa cenderung lebih menyukai pembelajaran yang menarik dan akan membuat siswa penasaran serta siswa menjadi aktif dalam proses belajar.

Tidak hanya bermanfaat bagi guru, penggunaan aplikasi zoom juga memberikan manfaat yang baik bagi siswa untuk melaksanakan pembelajaran daring di masa pandemi. Manfaat tersebut diantaranya siswa lebih mudah memahami materi pembelajaran, meningkatkan semangat belajar siswa, dan menghilangkan rasa bosan dalam belajar daring.

Meskipun pembelajaran dilaksanakan secara daring, pemahaman siswa terhadap materi pelajaran yang diberikan oleh guru juga perlu diperhatikan. Pemahaman akan materi pelajaran oleh siswa tidak hanya memberikan pengaruh terhadap ketercapaian pembelajaran akan tetapi berpengaruh juga terhadap perkembangan kognitif siswa tersebut. Oleh karena itu di dalam pembelajaran daring penggunaan media online merupakan salah satu solusi agar siswa dapat memahami materi pelajaran dengan baik (Mustakim, 2020). Aplikasi zoom merupakan media berbasis multimedia yang memiliki fitur-fitur pendukung dalam memudahkan siswa untuk memahami materi. Sejalan dengan Monica \& Fitriawati (2020) yang mengungkapkan sebagian besar siswa dapat memahami materi melalui pembelajaran daring yang menggunakan aplikasi zoom.

Selain itu penggunaan zoom mampu meningkatkan semangat siswa untuk belajar dan menghilangkan rasa bosan untuk belajar daring. Kondisi pandemi saat ini semangat belajar siswa menjadi salah satu aspek yang sangat penting dalam pembelajaran. Salah satu strategi yang dapat dilakukan guru agar siswa bersemangat dan tidak bosan belajar daring yaitu dengan memfasilitasi siswa agar dapat belajar bersama teman-temannya. Karena belajar bersama dengan teman sebaya akan membuat siswa lebih semangat untuk belajar dan ketika siswa merasa bingung, bimbang, dan bosan maka teman sebaya yang bisa mengurangi perasaan tersebut (Ningsih \& Djumali, 2020). Aplikasi zoom dapat menjadi media untuk melakukan pembelajaran bersama-sama, karena memiliki video conference yang mampu menampung banyak peserta. Pembelajaran menggunakan zoom, membuat guru dapat menampilkan materi pembelajaran dan 
Eko, Muhammad, Nurlaili. Analisis Manfaat Penggunaan Aplikasi... menjelaskannya secara bersamaan kepada siswa. Hal tersebut dikarenakan zoom memiliki fitur share screen yaitu fitur yang dapat menampilkan materi ajar baik berupa power point, video, dokumen, dan pdf yang membuat pembelajaran menyenangkan (Kurniawansyah, 2020).

Berdasarkan hasil penelitian dan pembahasan yang telah dipaparkan, maka dapat ditarik kesimpulan bahwa pembelajaran daring di masa pandemi saat ini harus dapat berjalan dengan efektif. Salah satu media yang dapat digunakan guru dalam pembelajaran daring adalah aplikasi zoom. Penggunaan aplikasi ini mampu memberikan manfaat yang baik bagi guru dan siswa, sehingga pembelajaran daring dapat berjalan dengan efektif.

\section{SIMPULAN}

Akibat dari adanya pandemic Covid-19 menyebabkan berubahnya sistem pendidikan yang ada, yang semulanya pendidikan dilakukan tatap muka berubah menjadi daring. Pembelajaran secara daring menuntut setiap pendidik untuk memanfaatkan perkembangan teknologi yang ada. Aplikasi zoom merupakan salah satu produk dari perkembangan teknologi saat ini, selain itu zoom dapat digunakan sebagai media pembelajaran daring.

Zoom yang digunakan sebagai media pembelajaran daring dimasa pandemi memberikan manfaat yang baik bagi guru dan siswa. Manfaat bagi guru diantaranya memudahkan mencapai tujuan pembelajaran, memudahkan berinteraksi bersama siswa, memberikan variasi dalam pembelajaran daring, menciptakan pembelajaran daring yang aktif , sedangkan manfaat penggunaan zoom bagi siswa diantaranya memudahkan memahami materi, meningkatkan semangat belajar daring, menghilangkan rasa bosan belajar daringManfaat yang dirasakan guru dan siswa tersebut memberikan dampak yang positif dalam pembelajaran daring sehingga menjadi lebih efektif.

\section{DAFTAR RUJUKAN}

Anshori, S. (2018). Pemanfaatan Teknologi Informasi Dan Komunikasi Sebagai Media Pembelajaran. Civic-Culture: Jurnal Ilmu Pendidikan PKn dan Sosial Budaya, 2(1). 
Eko, Muhammad, Nurlaili. Analisis Manfaat Penggunaan Aplikasi...

Brahma, I. A. (2020). Penggunaan zoom sebagai pembelajaran berbasis online dalam mata kuliah sosiologi dan antropologi pada mahasiswa PPKN di STKIP Kusumanegara Jakarta. Aksara: Jurnal Ilmu Pendidikan Nonformal, 6(2), 97102.

Buana, C. A. (2020). Penerapan desain rencana pembelajaran sebagai upaya membangun interaksi dalam pembelajaran daring (Doctoral dissertation, Universitas Pelita Harapan).

Handarini, O. I., \& Wulandari, S. S. (2020). Pembelajaran Daring Sebagai Upaya Study From Home (SFH) Selama Pandemi Covid 19. Jurnal Pendidikan Administrasi Perkantoran (JPAP), 8(3), 496-503.

Hasbiansyah, O. (2008). Pendekatan fenomenologi: Pengantar praktik penelitian dalam Ilmu Sosial dan Komunikasi. Mediator: Jurnal Komunikasi, 9(1), 163-180.

Ismawati, Dwi, and Iis Prasetyo. 2020. "Efektivitas Pembelajaran Menggunakan Video Zoom Cloud Meeting Pada Anak Usia Dini Era Pandemi Covid-19.” Jurnal Obsesi : Jurnal Pendidikan Anak Usia Dini 5(1): 665.

Kuntarto, E., \& Asyhar, R. (2016). Pengembangan Model Pembelajaran Blended Learning Pada Aspek Learning Design Dengan Platform Media Sosial Online Sebagai Pendukung Perkuliahan Mahasiswa. Repository Unja.

Kurniasari, A., Pribowo, F. S. P., \& Putra, D. A. (2020).Analisis Efektivitas Pelaksanaan Belajar Dari Rumah (Bdr) Selama Pandemi Covid-19. Jurnal Review Pendidikan Dasar: Jurnal Kajian Pendidikan Dan Hasil Penelitian, 6(3), 246-253.

Kurniawansyah, A. S. (2020). Kolaborasi Whatsapp Group, Zoom Cloud Meeting, Dan Google Drive Sebagai Formula Dalam Pelaksanaan Kegiatan Perkuliahan Online Di Masa Pandemi Covid-19. JURNAL MEDIA INFOTAMA, 16(2).

Liu, A. N. A. M. M., \& Ilyas, I. (2020). Pengaruh Pembelajaran Online Berbasis Zoom Cloud Meeting Terhadap Hasil Belajar Mahasiswa Fisika Universitas Flores. Jurnal Pendidikan Fisika Dan Keilmuan (JPFK), 6(1), 34-38. 
Eko, Muhammad, Nurlaili. Analisis Manfaat Penggunaan Aplikasi...

Miles, M. B. \& Huberman, A. M. (2007). Analisis Data Kualitatif. Diterjemahkan oleh Rohidi. Jakarta: UI-Press.

Monica, J., \& Fitriawati, D. (2020). Efektivitas Penggunaan Aplikasi Zoom Sebagai Media Pembelajaran Online Pada Mahasiswa Saat Pandemi Covid-19. Jurnal Communio: Jurnal Jurusan Ilmu Komunikasi, 9(2), 1630-1640.

Monica, J., \& Fitriawati, D. (2020). Efektivitas Penggunaan Aplikasi Zoom Sebagai Media Pembelajaran Online Pada Mahasiswa Saat Pandemi Covid-19. Jurnal Communio: Jurnal Jurusan Ilmu Komunikasi, 9(2), 1630-1640.

Mustakim, M. (2020). Efektivitas pembelajaran daring menggunakan media online selama pandemi covid-19 pada mata pelajaran matematika. Al asma: Journal of Islamic Education, 2(1), 1-12.

Mustakim, M. (2020). Efektivitas pembelajaran daring menggunakan media online selama pandemi covid-19 pada mata pelajaran matematika. Al asma: Journal of Islamic Education, 2(1), 1-12.

Ningsih, L. K., \& Djumali, M. P. (2020). Kejenuhan Belajar Masa Pandemi Covid-19 Siswa SMTA Di Kedungwungu Indramayu (Doctoral dissertation, Universitas Muhammadiyah Surakarta).

Pakpahan, R., \& Fitriani, Y. (2020). Analisa pemanfaatan teknologi informasi dalam pembelajaran jarak jauh di tengah pandemi virus corona covid-19. Journal of Information System, Applied, Management, Accounting and Research, 4(2), 3036.

Putria, H., Maula, L. H., \& Uswatun, D. A. (2020). Analisis proses pembelajaran dalam jaringan (daring) masa pandemi covid-19 pada guru sekolah dasar. Jurnal Basicedu, 4(4), 861-870.

Riyana, C. (2019). Produksi Bahan Pembelajaran Berbasis Online. Universitas Terbuka.

Rosyid, N. M., Thohari, I., \& Lismanda, Y. F. (2020). Penggunaan Aplikasi Zoom Cloud Meetings Dalam Kuliah Statistik Pendidikan Di Fakultas Agama Islam Universitas Islam Malang. Vicratina: Jurnal Pendidikan Islam, 5(11), 46-52. 
Eko, Muhammad, Nurlaili. Analisis Manfaat Penggunaan Aplikasi...

Sadikin, A., \& Hamidah, A. (2020). Pembelajaran Daring di Tengah Wabah Covid19:(Online Learning in the Middle of the Covid-19 Pandemic). Biodik, 6(2), 214-224.

Siahaan, M. (2020). Dampak Pandemi Covid-19 Terhadap Dunia Pendidikan. Dampak Pandemi Covid-19 Terhadap Dunia Pendidikan, 20(2).

Sofyana, L., \& Rozaq, A. (2019). Pembelajaran Daring Kombinasi Berbasis Whatsapp Pada Kelas Karyawan Prodi Teknik Informatika Universitas Pgri Madiun. Jurnal Nasional Pendidikan Teknik Informatika: JANAPATI, 8(1), 8186.

Solihin, A. (2020). Pembelajaran online dengan Aplikasi Zoom Meeting di Kelas 5 SDN 1 Selaawi di Masa Pandemi Covid-19. Gunahumas, 3(2).

Suryani, A. (2010). ICT in education: Its benefits, difficulties, and organizational development issues. Jurnal Sosial Humaniora (JSH), 3(1), 13-33.

Wahidmurni, W. (2017). Pemaparan metode penelitian kualitatif. 1-17. 